\title{
Relationships between Environmental Initiatives and Impact Reductions for Construction Companies
}

\author{
Andrew S. Chang ${ }^{1}$, Claudia Canelas ${ }^{1}$ and Yi-Ling Chen ${ }^{2, *}$ \\ 1 Department of Civil Engineering, National Cheng Kung University, Tainan 701, Taiwan; \\ anschang@mail.ncku.edu.tw (A.S.C.); claucanelas@outlook.com (C.C.) \\ 2 Department of Accounting, Shih Chien University, Taipei 104, Taiwan \\ * Correspondence: jchen7571@gmail.com
}

check for updates

Citation: Chang, A.S.; Canelas, C.; Chen, Y.-L. Relationships between Environmental Initiatives and Impact Reductions for Construction Companies. Sustainability 2021, 13, 8061. https://doi.org/10.3390/ su13148061

Academic Editor: Antonio Caggiano

Received: 1 June 2021

Accepted: 12 July 2021

Published: 19 July 2021

Publisher's Note: MDPI stays neutral with regard to jurisdictional claims in published maps and institutional affiliations.

Copyright: (c) 2021 by the authors. Licensee MDPI, Basel, Switzerland. This article is an open access article distributed under the terms and conditions of the Creative Commons Attribution (CC BY) license (https:/ / creativecommons.org/licenses/by/ $4.0 /)$.

\begin{abstract}
A company undertakes environmental initiatives to reduce environmental impact from their activities; however, the impact reduction effect of these initiatives is not clear. This study investigated the environmental initiatives and impact indicators disclosed in forty corporate social responsibility (CSR) reports of construction companies and determined the relationships between the initiatives and indicators. The results demonstrated that the likelihood of an initiative reducing environmental impacts was approximately $25 \%$ on average, meaning that one in four companies was able to successfully implement initiatives. The energy consumption reduction from initiatives had the highest probability, at $40 \%$, and water consumption reduction had only $9.4 \%$. This study contributes to making explicit relationships between initiatives and impact reductions possible. A company can verify the effectiveness of initiatives by examining the values of their corresponding indicators before implementing environmental initiatives.
\end{abstract}

Keywords: corporate social responsibility; environmental initiatives; environmental performance indicators; construction companies; global reporting initiative

\section{Introduction}

Business activities have direct and indirect impacts on the environment. The construction industry is one of the largest industries in terms of investment, employment, and contribution to GDP. It is also one of the largest consumers of energy and producers of waste [1-3].

In recent times, the construction industry has been adopting environmental initiatives or practices, such as waste management that cause less harm, pollution, waste, or damage to the environment. Companies may adopt formal environmental management systems to establish environmental goals known as indicators and to implement initiatives to achieve goals and evaluate their environmental performance $[4,5]$.

Environmental indicators are important for effectively managing and monitoring the environmental impact caused by the activities of a company. Indicators provide clear information about a company's level of sustainability, its environmental impacts, and the state of the environment [6]. This information provides an overview of relevant progress and highlights problem areas [7].

Environmental practices guide the actions that companies take to achieve their environmental objectives [8]. Implementing environmental practices in construction activities has several benefits [9]. For example, the adoption of environmental practices leads to an increase in energy and resource efficiencies and improved waste management during project implementation [10]. Green construction, involving practices such as responsible consumption, can help reduce the use of water, energy, and materials [11]. Waste management ensures that the generation of construction waste and the use of hazardous materials are prevented or reduced [12-14]. Environmental innovations also have a positive effect on a firm's environmental performance [15]. 
Currently, construction companies publish corporate social responsibility (CSR) reports as a means to communicate their sustainable performance and to gain a competitive advantage. Global Reporting Initiative (GRI) is the best-known framework for the voluntary reporting of CSR undertaken by businesses and organizations worldwide [16]. The GRI guidelines outline environmental performance indicators and request management approaches to determine whether companies are making attempts to reduce the impact their activities have on the environment [17].

CSR is mostly voluntary; companies can decide on the information they would like to include in their CSR reports. A CSR report should present quantitative and qualitative information on an organization's sustainable performance in a balanced manner. In a CSR report, quantitative information is provided through performance indicators and qualitative information usually is descriptions of initiatives or practices. Providing stakeholders with both quantitative and qualitative information is crucial to make them aware of the extent to which sustainable objectives are being met and to highlight the aspects that need improvement. However, many organizations do not provide balanced CSR reports. They either focus more on qualitative information or provide qualitative information that does not accord with the quantitative information they provide [18].

Moreover, it is unclear whether the initiatives undertaken by a company improve environmental performance. Studies identified the relationships between environmental initiatives and environmental performance $[19,20]$. However, the influence of initiatives on impact reduction was not discussed. To address its importance, initiative implementation should be studied with corresponding environmental impacts [21]. To ensure the enforcement of initiatives, the construction process needs to be closely monitored to elucidate its effect [22]. Therefore, the relationships between initiatives and the reported impacts of these initiatives need to be verified.

The objective of this study was to investigate the relationships between environmental initiatives and their performance using the CSR reports of construction companies.

The research framework is shown in Figure 1. Using CSR reports, this study analyzed the initiatives/practices and linked them to indicator disclosure to verify environmental performance. Studying these relationships contributes to determining the extent to which environmental initiatives help reduce environmental impacts.

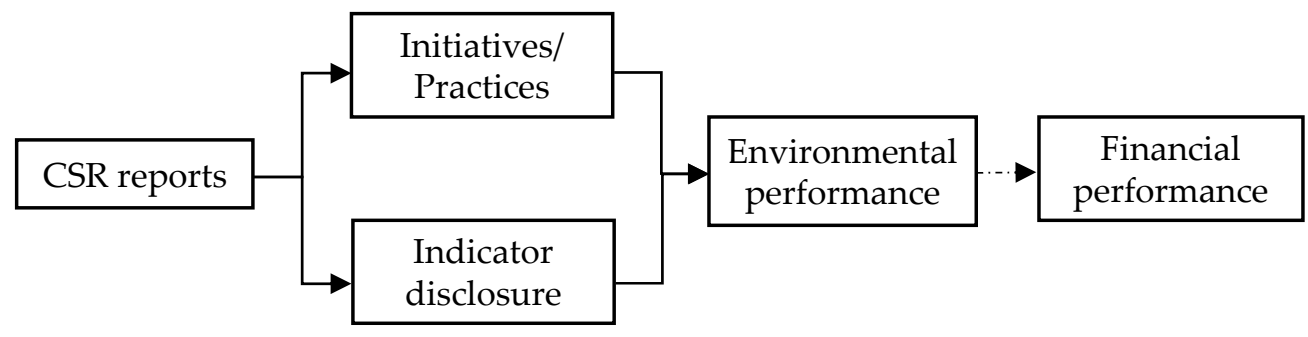

Figure 1. Research framework.

Studies have attempted to identify the relationship (with dotted line in Figure 1) between environmental performance and financial performance; some of them are discussed in the literature review section. However, an analysis of this relationship is beyond the scope of this study.

Sustainability includes environmental, economic and social perspectives, but this study only focused on environmental perspective. The economic or cost aspect of environmental initiatives can be analyzed to determine their effectiveness, as suggested in Discussion and for future research. Social aspects, such as concerns of interested parties, can be studied when research issues are appropriate, such as assessing the significance of environmental impacts [21].

The structure of this paper is as follows. In Section 2, relevant literature is reviewed. In Section 3, the research method is described. In Sections 4 and 5, the results and discussion are presented and in Section 6, conclusions are drawn. 


\section{Literature Review}

In this section, relevant studies on sustainability reporting and the quality thereof, as well as environmental indicators and practices, and environmental disclosure and performance are reviewed.

\subsection{Sustainability Reporting and Report Quality}

A CSR report provides information on the economic, environmental, and social dimensions of an organization. However, the completeness and credibility of these reports are subject to some concerns [23]. Roca et al. [24] found that many sustainability reports might not provide accurate and complete information on corporate social and environmental impacts. Habek et al. [25] showed that the quality level of studied CSR reports was generally low, and the legal obligation of CSR data disclosure had a positive effect on the quality of CSR reports.

Brammer et al. [26] examined patterns in the quality of environmental disclosures made by 450 large UK companies across various industry sectors. They found that the quality of disclosures depended on the size of the company; they found that larger firms and firms in sectors that most affect the environment tended to make high-quality disclosures. Fernandez-Feijoo et al. [27] reviewed 4496 CSR reports published between 2008 and 2010 of companies from 11 countries and across 38 industries. They measured the disclosure and credibility of the CSR information and found that CSR reporting was dependent on multiple variables, particularly external perception and external assurance.

Daub [1] found that a relatively high degree of emphasis was placed on qualitative information in most corporate sustainability reports. However, research was scarce on the indicators used to convey quantitative information in sustainability reports. Bewley et al. [28] found that firms that received more news media coverage of their environmental exposure, had a higher propensity to pollute the environment, and received more political exposure, were more likely to disclose general environmental information.

The quality of sustainability reporting and indicator disclosure may vary. For example, companies may provide more information on some indicators and less on others. Some companies may publish only positive information in their reports and omit negative information. Some companies provide external assurance, whereas others do not. Consequently, these reports may appear to lack credibility [29]. Habek [30] confirmed the existence of a positive relationship between the use of the GRI guidelines in the development of a CSR report and the quality level of that report.

\subsection{Environmental Indicators and Practices}

Environmental impacts can be represented by environmental indicators. They provide a measurement of business operation accomplishment and are fundamental to the improvement of operations [31]. A set of indicators can be used to provide information on the overall state or quality of the environment [6]. From amidst a large amount of environmental information, environmental indicators provide concise key data. On such a basis, environmental targets can be supported with concrete figures, making the definition and pursuit of environmental targets controllable and verifiable [7].

Studies have used objective data, such as carbon emissions, water withdrawal by source, and waste type or weight, to measure environmental performance [32,33]. In the construction sector, reductions in energy consumption, pollution, emissions, waste, and hazardous material are common indicators for measuring environmental performance [34]. For example, $64 \%$ of the 250 large companies published reports related to reductions in areas such as pollution, waste, carbon emissions, and energy use [18]. The reuse and recycling of waste have also been regarded as strategic alternatives for reducing waste from construction $[35,36]$.

GRI guidelines suggest the use of indicators to measure an organization's performance [17]. Examples of generally applicable environmental indicators include total energy use, total water use, greenhouse gas emissions in tons of $\mathrm{CO}_{2}$ equivalent, total 
waste, and supplier performance. Companies are encouraged to follow the guidelines to promote greater comparability; however, companies are free to decide the indicators as well as the number of indicators they would like to use. As companies gain experience and improve their data collection systems, they should begin tracking more indicators [37].

Disclosures of information on the sustainable initiatives adopted by a company to address environmental impacts are as important as information on the impacts. Birkeland [38] noted the substantial potential to reduce the adverse impacts of construction activities on the environment through the adoption of environmental practices. Environmental practices consist of reducing renewable and nonrenewable energy consumption and minimizing waste through its reuse, recycling, reduction, and recovery [39]. Batista et al. [40] identified sustainable practices performed by large corporations, and the environmental performance is measured by the practices that contribute to reducing the consumption of natural resource.

Son et al. [41] surveyed construction firms regarding their levels of awareness of sustainable construction practices and preparedness to implement them. They found that various strategies and programs for sustainable construction were already in place; however, these strategies and programs cannot be widely implemented unless and until a sufficiently high level of know how spreads among contractors. Alazzani et al. [42] studied GRI environmental reporting and found that companies exhibited more commitment to environmental issues in countries where stakeholder engagement was more prevalent.

\subsection{Environmental Initiatives/Disclosure and Performance Relationships}

Figure 1 can be referenced when the initiatives and performance relationships are reviewed. Clarkson et al. [43] and Bednarova et al. [44] found a positive relationship between environmental performance and environmental disclosure; in general, firms that cause more pollution make more environmental disclosures. Latridis [45] predicted that environmental disclosure and environmental performance were positively correlated; companies that have better environmental initiatives provide more environmental disclosures. Walls et al. [46] found that there was a relationship between corporate governance and environmental performance. Geng et al. [19] revealed that green supply chain management (GSCM) practices lead to better economic, environmental, operational, and social performance. Ardito et al. [20] found that market, environmental management, and GSCM orientations all have a positive effect on sustainable use of carbon-based fuels, energy, and water, as well as waste reduction.

Chen et al. [47] analyzed CSR and financial reports of manufacturing companies and found that environmental management practices do not have a positive correlation with financial performance. Chen et al. [48] indicated that, among environmental practices, onsite pollution abatement has a significant influence on the short- and long-term financial performance of construction firms. Li et al. [49] showed that both green initiatives and green performance have a significant impact on financial performance; the impact of green performance on financial performance is not immediate and may take more than one year to become noticeable. Hang et al. [50] found that increasing environmental performance had no short-term effect on financial performance; however, in the long term, a firm may benefit from increasing its environmental performance. Nuber et al. [51] investigated the impact of sustainability performance on financial performance and identified a U-shaped relationship between them.

\section{Research Method}

This study adopted a content analysis method to analyze the relationships between the environmental initiatives and indicators disclosed in CSR reports. Forty total CSR reports, encompassing the annual CSR reports of eight companies for five consecutive years, were analyzed. The CSR report is a good resource for studying environmental management practices [47]. 
Content analysis is a research technique that is used to obtain replicable and valid inferences from texts to determine their contexts [52]. In this study, the texts were the environmental initiatives and disclosed indicators in CSR reports, and they were examined, analyzed, and compared. Content analysis is useful for analyzing motivations for themes of, and approaches to, CSR as well as corporate social disclosures [53,54].

CSR reports from 2010 to 2014 were chosen because almost all eight companies followed GRI versions 3.0 and 3.1, in which the 30 provided environmental indicators are the same. GRI version 4 was published in 2013, with changed indicators and most companies adopting it beginning from 2015. The number of environmental indicators was increased to 34, and the definitions and scopes of some of the studied indicators were different from those in the earlier versions. It becomes difficult to track the values of indicators crossing different versions. Nevertheless, the reports of the five years provided plenty of initiatives and indicator values for analysis and comparison in this study.

Eight construction companies were selected as cases, as shown in Table 1. Three selection criteria were: (1) they represented a general overview of sustainability reporting in the construction sector, (2) they were from different countries or continents, and (3) they published CSR reports for the five years under study. The first four (Codes A, B C and D) were selected from the six construction companies discussed in the report "A Snapshot of Sustainability Reporting in the Construction and Real Estate Sector" published by GRI [55]; these companies published CSR reports in earlier years. The other four were selected with discretion but from the largest companies in different countries. The eight companies are headquartered in Europe, America, Asia, or Africa and published CSR reports for the five years under study. The CSR reports of these companies can be found in GRI's Sustainability Disclosure Database [56]. Although the number of eight cases may seem small, Eisenhardt [57] stated that assessing 4-10 cases is typically sufficient for an analysis to yield meaningful results. In actual fact, more than 100 initiatives and 160 indicator values in forty samples of CSR reports were evaluated.

Table 1. General information on the eight companies under study.

\begin{tabular}{|c|c|c|c|c|c|}
\hline Code & Company & Country & $\begin{array}{c}\text { Year } \\
\text { Founded }\end{array}$ & Business Lines & $\begin{array}{l}2014 \text { Revenue } \\
\text { (Millions } \\
\text { of USD) }\end{array}$ \\
\hline A & Hochtief & Germany & 1873 & $\begin{array}{l}\text { Buildings, Civil Engineering, } \\
\text { Infrastructure facilities, Real estate }\end{array}$ & 8200 \\
\hline B & Fluor & USA & 1912 & $\begin{array}{c}\text { Energy and Chemicals, Power and } \\
\text { Electricity plants, Mining and } \\
\text { Metals, Industry }\end{array}$ & 21,500 \\
\hline $\mathrm{C}$ & Obayashi & Japan & 1892 & $\begin{array}{c}\text { Buildings, Urban and Recreational areas, } \\
\text { Power plants, Industry, } \\
\text { Infrastructure, Waterworks }\end{array}$ & 15,700 \\
\hline $\mathrm{D}$ & Group Five & South Africa & 1974 & $\begin{array}{c}\text { Mining, Power and Electricity, Oil and } \\
\text { gas, Water and environment, Real } \\
\text { Estate, Infrastructure }\end{array}$ & 1010 \\
\hline $\mathrm{E}$ & CTCI & Taiwan & 1974 & $\begin{array}{l}\text { Chemical and petrochemical, Steel and } \\
\text { nonferrous, Infrastructure, Waste to } \\
\text { energy fields }\end{array}$ & 1740 \\
\hline $\mathrm{F}$ & $\begin{array}{l}\text { Hyundai } \\
\text { Engineering and } \\
\text { Construction }\end{array}$ & South Korea & 1947 & $\begin{array}{l}\text { Building works, Civil Works, } \\
\text { Infrastructure, Renewable Energy, } \\
\text { Industrial Plants, Power Plants }\end{array}$ & 14,100 \\
\hline G & OHL Group & Spain & 1999 & $\begin{array}{c}\text { Railway Infrastructures, Buildings, } \\
\text { Transportation, Maritime works, } \\
\text { Hydraulic works }\end{array}$ & 4000 \\
\hline $\mathrm{H}$ & ICA Enterprises & Mexico & 1947 & $\begin{array}{l}\text { Transportation infrastructure, } \\
\text { Waterworks, Energy, Social and } \\
\text { commercial Buildings, Oil }\end{array}$ & 2005 \\
\hline
\end{tabular}


The GRI guidelines provide 30 environmental indicators, labeled EN1-EN30, in version 3.1. Among them, four quantitative indicators were chosen, as listed in Table 2, because they were disclosed by all eight companies and are related to construction activities [55,58]; energy, water and GHG emissions are also grouped as key negative impact on sustainability [59]. Moreover, these indicators were disclosed with values that are easy to identify and compare. Adopting the indicators overcomes the uncertainty in the identification and assessment of environmental impacts [21]. Therefore, their values were chosen to indicate the impacts described in this study.

Table 2. Four indicators analyzed.

\begin{tabular}{ccc}
\hline Aspect & Indicators & Description \\
\hline Energy & EN3 & Direct energy consumption \\
Water & EN8 & Total water withdrawal \\
Emissions & EN16 & Total weight of direct and indirect greenhouse \\
Waste & EN22 & Total emissions \\
\end{tabular}

After the indicators were determined, the environmental initiatives written in the CSR reports were examined. The initiatives are the actions companies take to reduce their environmental impacts. For analyzing the initiatives and indicators, the indicator values in 2010 (starting year) were first used for comparison. A relationship was identified if an initiative reported in one year resulted in a decrease in the value of an indicator in the following year. If an indicator value increased after decreasing, the reported initiatives were of too broad a focus, or no initiative or indicator information was reported, this was considered to indicate no relationship. A relationship may, however, appear after a time lag between implementation of an initiative and manifestation of its indicator value [47]. Therefore, the indicator values were reviewed for five years.

\section{Results}

The number of relationships between initiatives and indicators was calculated for the eight companies. The rule used to establish a relationship is "an initiative is implemented in a year and its corresponding indicator's value decreases in the next year." For example, the relationships between the initiatives and indicators of two companies with a high and low number of relationships were explained.

Table 3 presents the relationships between the initiatives and impacts of Company G. For EN3, an initiative of auto generated renewable (solar) energy was implemented in 2010. A decrease in energy consumption was observed, with a reduction from $8797 \mathrm{TJ}$ in 2010 to $4190 \mathrm{TJ}$ in 2011. Hence, a relationship was evident for 2011. In 2013, the energy consumption increased to $4190 \mathrm{TJ}$; therefore, there was no relationship that year. A relationship was observed again in 2014 as the energy consumption dropped to 2978 TJ. This was attributed to the fact that, in 2013, the initiatives of environmental management system (EMS) certification and energy audits were adopted. Therefore, three relationships were found for EN3.

The number of relationships was checked with respect to three other indicators. Zero, two, and three relationships were found for EN8, EN16, and EN22, respectively. Therefore, Company $\mathrm{G}$ exhibited a total of eight relationships, the highest among all of the companies.

Figure 2 shows the decreases in the energy (EN3) and water (EN8) consumption of Company G. Between 2010 and 2014, the initiatives resulted in increases in the use of solar energy and energy management audits; using solar energy, in turn, reduced direct energy consumption from fossil fuels. During this period, energy consumption decreased by approximately $66 \%$, from 8797 to 2978 TJ. This indicates that the initiatives helped to decrease energy consumption. A slight increase in energy consumption was observed in 2013, which is attributable to consumption by their Latin American division. 
Table 3. Relationships between initiatives impacts of Company G.

\begin{tabular}{|c|c|c|c|c|}
\hline \multicolumn{2}{|c|}{ Indicators } & Initiatives & Impacts & Rela. \\
\hline \multirow{5}{*}{$\begin{array}{l}\text { EN3 } \\
\text { Energy }(\mathrm{TJ})\end{array}$} & 2010 & Renewable energy & 8797 & \\
\hline & 2011 & $\begin{array}{c}\text { Partners with LEED and USGBC, Energy awareness } \\
\text { and energy saving actions. }\end{array}$ & 4190 & $\checkmark$ \\
\hline & 2012 & Increased renewables, Energy management & 4100 & $\checkmark$ \\
\hline & 2013 & EMS certification, Energy audits & 4190 & \\
\hline & 2014 & Increased renewable energy, EMS certificate & 2978 & $\checkmark$ \\
\hline \multirow{6}{*}{$\begin{array}{c}\text { EN8 } \\
\text { Water } \\
\left(1000 \mathrm{~m}^{3}\right)\end{array}$} & & Subtotal & & 3 \\
\hline & 2010 & - & 11,945 & \\
\hline & 2011 & - & 10,551 & \\
\hline & 2012 & - & 2888 & \\
\hline & 2013 & - & 3804 & \\
\hline & 2014 & Recycled water technologies & 4827 & \\
\hline \multirow{6}{*}{$\begin{array}{c}\text { EN16 } \\
\mathrm{CO}_{2} \\
\text { Emissions (1000 tons) }\end{array}$} & \multicolumn{2}{|r|}{ Subtotal } & & \multirow[t]{2}{*}{0} \\
\hline & 2010 & Reduction in polluting vehicles and business travel & 424 & \\
\hline & 2011 & Sale of business line & 417 & $\checkmark$ \\
\hline & 2012 & Carbon footprint measures & 303 & $\checkmark$ \\
\hline & 2013 & Carbon footprint measures offset & 6588 & \\
\hline & 2014 & Less use of fossil fuels & 6515 & $\checkmark$ \\
\hline \multicolumn{4}{|c|}{ Subtotal } & 3 \\
\hline \multirow{5}{*}{$\begin{array}{c}\text { EN22 } \\
\text { Waste } \\
\text { (1000 tons) }\end{array}$} & 2010 & Waste reduction optimization & 16,320 & \\
\hline & 2011 & - & 3843 & $\checkmark$ \\
\hline & 2012 & - & 6731 & \\
\hline & 2013 & Waste management technologies & 21,469 & \\
\hline & 2014 & $\begin{array}{l}\text { Biomass plant management, waste management } \\
\text { technologies }\end{array}$ & 14,823 & $\checkmark$ \\
\hline \multicolumn{4}{|c|}{ Subtotal } & 2 \\
\hline \multicolumn{4}{|c|}{ Total } & 8 \\
\hline
\end{tabular}

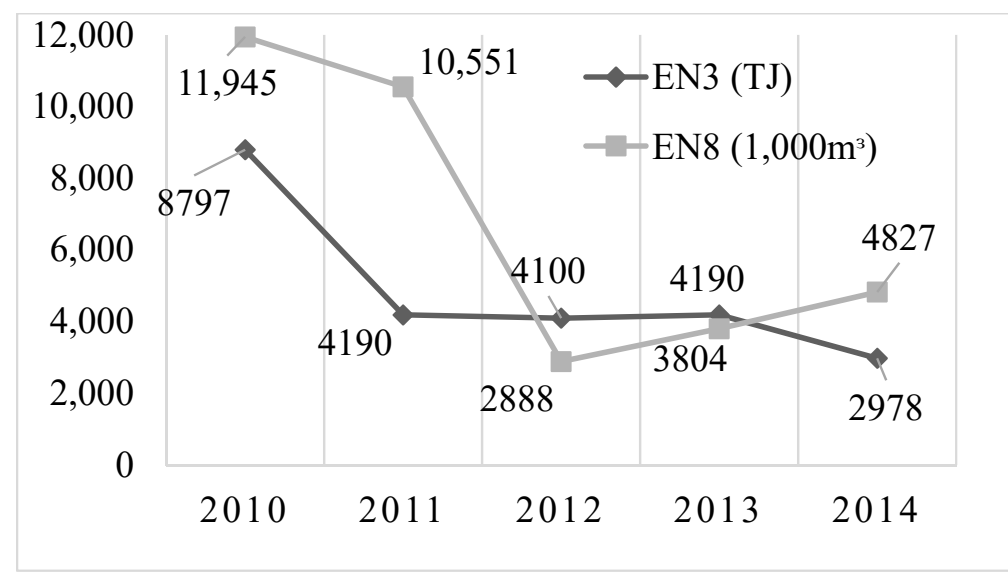

Figure 2. EN3 and EN8 of Company G. 
The amount of water withdrawal (EN8) also showed a decreasing trend. The amount of water withdrawal decreased by $59.6 \%$, from $11,945,000$ to $4,827,000 \mathrm{~m}^{3}$. A significant decrease was observed in 2012, so the environmental business line was closed to reduce water use. In 2013-2014, water consumption increased because of the increase in construction activities.

Figure 3 shows the trends in EN16 and EN22. The $\mathrm{CO}_{2}$ emissions increased from 0.42 to 6.52 million tons during this period. They slightly decreased between 2011 and 2012 but increased significantly in 2013. The relevant report stated that the value of indirect emissions, scope 3, was recalculated. The emissions level from scope 3, which includes a company's upstream and downstream activities, was higher than those from scope 1 and scope 2 [56]. A slight decrease in the amount of generated waste (E22) was observed during the period 2010 to 2014, from 16 to 15 million tons. The fluctuation in values during this period may be due to a decrease or increase in construction activities.

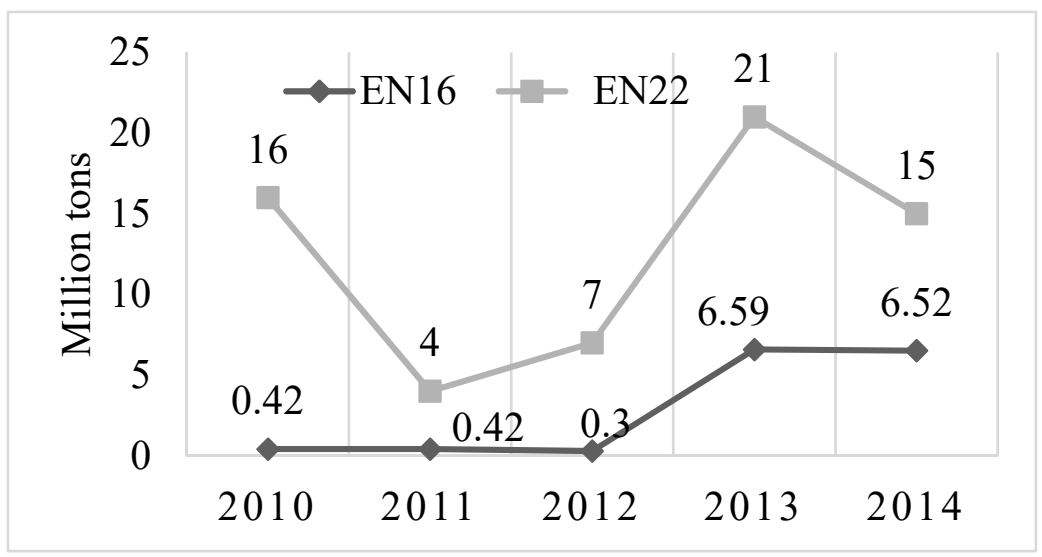

Figure 3. EN16 and EN22 of Company G.

Table 4 presents the relationships between the initiatives and impacts of Company A. Only one relationship in total was checked. For EN3, the initiatives of LEED certification and the adoption of renewable energy technologies were reported in 2010 as well as in the following four years. Energy consumption was 370 TJ in 2010, and it considerably increased to $47,303 \mathrm{TJ}$ in 2011 . Hence, no relationship was verified. Although the energy consumption decreased to 8011 TJ in 2012, no relationship was found. It is difficult to believe that the same initiatives reported in the previous year brought about such a large decrease in energy consumption. For EN22, only one relationship was found, albeit barely, in 2011. The initiative of reuse and recycle was adopted in 2010, and the amount of waste generated decreased from 510,000 to 499,000 tons in 2011. This is the only relationship identified for the company.

Energy consumption (EN3) fluctuated during the period under study, as shown in Figure 4. It is unclear whether energy consumption decreased because of the adopted initiatives. The decrease in energy consumption was possibly due to a decrease in construction activities. However, the exact reason for this decrease is not known, and it cannot be determined using the method employed in our study; more information on the company's construction contract amounts needs to be obtained through personnel interviews. For EN8, the reported initiatives were treatment plants and modern technologies for all five years. Water withdrawal increased from $340,000 \mathrm{~m}^{3}$ to $37,128,000 \mathrm{~m}^{3}$. Therefore, no relationships were checked. Energy consumption increased and water withdrawal decreased from 2013 to 2014. Further investigation should be undertaken to discern the reason for the different trends in the energy and water consumption of a company. 
Table 4. Relationships between initiatives and impacts of Company A.

\begin{tabular}{|c|c|c|c|c|}
\hline \multicolumn{2}{|c|}{ Indicators } & Initiatives & Impacts & Rela. \\
\hline \multirow{5}{*}{$\begin{array}{c}\text { EN3 } \\
\text { Energy }(\mathrm{TJ})\end{array}$} & 2010 & LEED certifications, renewable energy & 370 & \\
\hline & 2011 & Same as above & 47,303 & \\
\hline & 2012 & Same as above & 8011 & \\
\hline & 2013 & Same as above & 12,485 & \\
\hline & 2014 & Same as above & 370 & \\
\hline \multicolumn{4}{|c|}{ Subtotal } & 0 \\
\hline \multirow{5}{*}{$\begin{array}{c}\text { EN8 } \\
\text { Water }\left(1000 \mathrm{~m}^{3}\right)\end{array}$} & 2010 & Treatment plants, modern technologies & 340 & \\
\hline & 2011 & Same as above & 671 & \\
\hline & 2012 & Same as above & 5074 & \\
\hline & 2013 & Same as above & 16,679 & \\
\hline & 2014 & Same as above & 37,128 & \\
\hline \multicolumn{4}{|c|}{ Subtotal } & 0 \\
\hline \multirow{5}{*}{$\begin{array}{c}\text { EN16 } \\
\mathrm{CO}_{2} \text { Emissions } \\
\text { (1000 tons) }\end{array}$} & 2010 & GHG emission management & 990 & \\
\hline & 2011 & Same as above & 1000 & \\
\hline & 2012 & Same as above & 900 & \\
\hline & 2013 & Same as above & 3500 & \\
\hline & 2014 & Same as above & 8844 & \\
\hline \multicolumn{3}{|r|}{ Subtotal } & & 0 \\
\hline \multirow{5}{*}{$\begin{array}{l}\text { EN22 } \\
\text { Waste (1000 tons) }\end{array}$} & 2010 & $\begin{array}{l}\text { Reuse and recycle, training to minimize waste } \\
\text { production. }\end{array}$ & 510 & \\
\hline & 2011 & Same as above & 499 & $\checkmark$ \\
\hline & 2012 & Same as above & 1062 & \\
\hline & 2013 & Same as above & 3011 & \\
\hline & 2014 & Same as above & 8364 & \\
\hline \multicolumn{4}{|c|}{ Subtotal } & 1 \\
\hline \multicolumn{4}{|c|}{ Total } & 1 \\
\hline
\end{tabular}

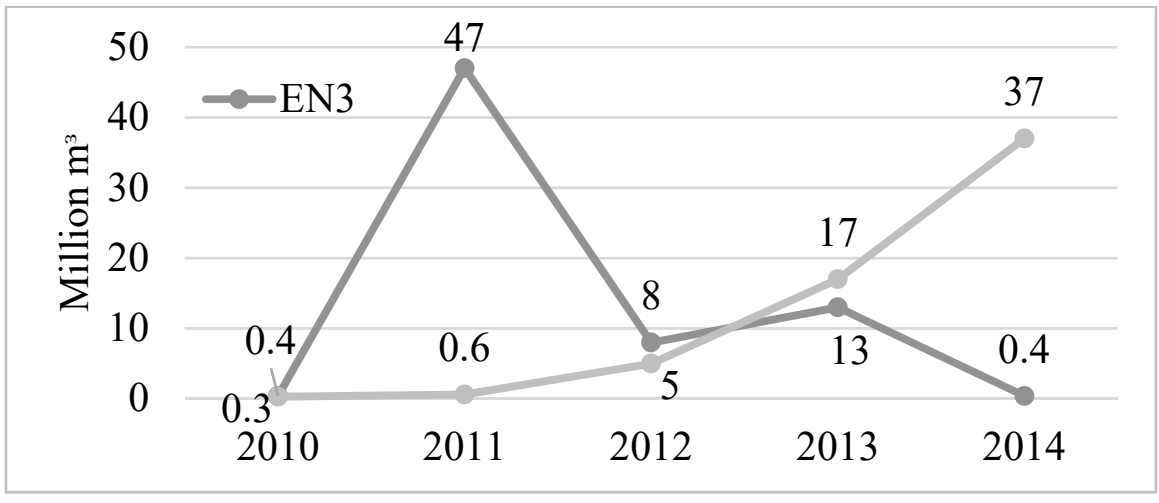

Figure 4. EN3 and EN8 of Company A.

The amount of $\mathrm{CO}_{2}$ emissions (EN16) and waste generated (EN22) increased in almost all five years, as shown in Figure 5, rendering it difficult to conclude that the initiatives reduced environmental impacts. 


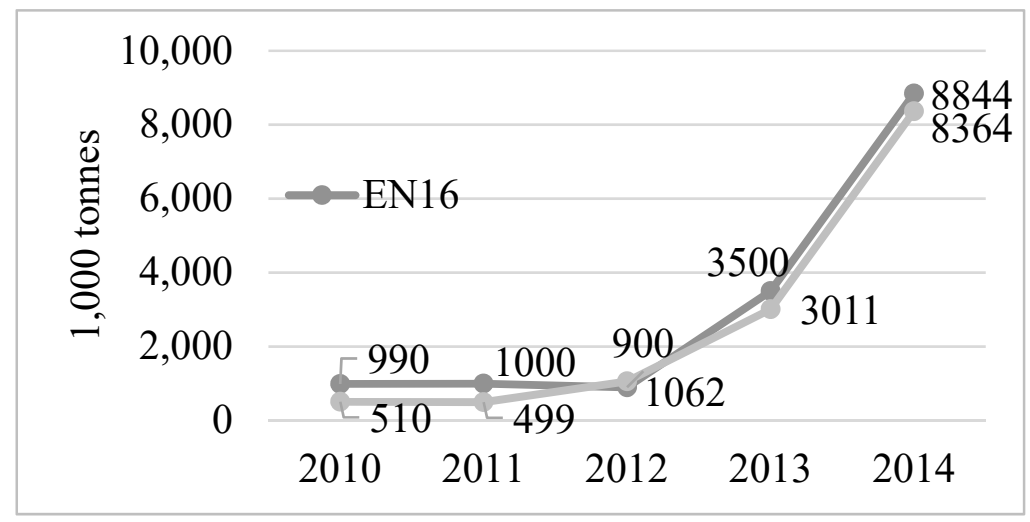

Figure 5. EN16 and EN22 of Company A.

Table 5 summarizes the number of relationships of the four indicators and eight companies. The percentage of relationships for each indicator is calculated by dividing the total number of relationships of the indicator by 32 , which is the maximum number of relationships attainable from the eight companies over four years (times), and then multiplying by 100 . For example, EN3 had a total of 13 relationships; therefore, the percentage of relationships is $13 / 32=40.6 \%$. In contrast, the percentage of relationships for a company is calculated by dividing the total number of relationships of the company by 16 (four indicators analyzed for four years) and multiplying by 100. For example, Company G had a total of eight relationships; therefore, the percentage of relationships is $8 / 16=50 \%$.

Table 5. Summary of relationships of initiatives and impacts.

\begin{tabular}{ccccccc}
\hline & Indicator & \multicolumn{7}{c}{ No. of Relationships } \\
\cline { 2 - 7 } Company & EN3 & EN8 & EN16 & EN22 & Total & Total/16 (\%) \\
\hline A & 0 & 0 & 0 & 1 & 1 & 6.3 \\
\hline B & 0 & 0 & 0 & 0 & 0 & 0 \\
\hline C & 0 & 0 & 0 & 1 & 1 & 6.3 \\
\hline D & 3 & 0 & 2 & 0 & 5 & 31.3 \\
\hline E & 3 & 2 & 1 & 2 & 8 & 50 \\
\hline F & 3 & 1 & 2 & 1 & 7 & 43.8 \\
\hline G & 3 & 0 & 2 & 3 & 8 & 50 \\
\hline H & 1 & 0 & 0 & 0 & 1 & 6.3 \\
\hline Total & 13 & 3 & 7 & 8 & 31 & \\
\hline Total/32 $(\%)$ & 40.6 & 9.4 & 21.9 & 25 & & 24.3 \\
\hline
\end{tabular}

Among the indicators, EN3 had the highest percentage of relationships, with $40.6 \%$. Thus, the likelihood that an initiative would reduce energy consumption is about $40 \%$. This is probably because energy has become a common understanding and goal for most construction companies, and related practices are available to use $[10,14]$. EN8 had only $9.4 \%$ of relationships; consequently, the likelihood for an initiative to reduce water consumption is only $9.4 \%$. This is probably because construction companies do not consider water an important resource because water is less expensive, and its use is less noticeable than that of energy [60].

Companies $\mathrm{E}$ and $\mathrm{G}$ had the highest number and percentage (eight and $50 \%$, respectively) of relationships between initiatives and impacts, followed by Company $\mathrm{F}$ with seven and $43 \%$, respectively. Company B had no relationships between initiatives and impacts. This may be because the initiatives were not successful in reducing impacts. The initiatives in this case need to be examined. Another possible reason for no relationships 
being observed is that the environmental data collected did not reflect reality, as in the prior scope 3 recalculation example. In this case, the CSR report data need to be better prepared.

The average percentage relationship was $24.3 \%$ for the indicators and companies. This means that one initiative had a likelihood of approximately $25 \%$ of reducing the environmental impact, or of one of four companies being able to undertake initiatives to reduce the environmental impact. This proportion is acceptable given that the relationships between initiatives and impacts have not been investigated to a considerable extent in either industry or academia; thus, companies have only partial knowledge of initiatives [41,61]. The relationship between environmental initiatives and performance for organizations in different industries needs to be investigated.

\section{Discussion}

The preceding section's analyses indicate that three factors would influence the relationships between initiatives and their impacts: amount of construction activity, content of initiatives, and money spent on initiatives. These three factors are discussed as follows:

Amount of construction activity. Construction companies rely on construction projects to remain in operation. When a company receives more projects or its contract revenue increases, construction activities and associated impacts increase accordingly. In this case, the influence of initiatives on reducing environmental impact is offset by the intensity of their construction activities. This factor was cited in many of the CSR reports to justify company environmental performance.

Content of initiatives. When an initiative does not reduce the environmental impact to an expected level, the contents of the initiative need to be examined to determine whether they are suitable. Sometimes an initiative is only a certification such as ISO 14001 for EMS. This type of initiative with established ISO administrative procedures is often not effectively implemented or does not reduce environmental impacts in the short term [62].

Money spent on initiatives. Initiatives are of many types and sizes, each having a different cost. Companies tend to undertake smaller initiatives because of cost constraints. However, the effect of these initiatives is often limited. Effective initiatives are usually expensive. Therefore, the cost involved in the implementation of an initiative needs to be considered to determine its effectiveness.

Why only the CSR reports from 2010 to 2014 were studied is clarified below. GRI guidelines were published four times in the past 20 years, so the number of environmental indicators was changed and the definitions and scopes of some indicators were different from those in earlier versions. For example, EN3 is "direct energy consumption by primary source" in version 3.1; however, it is "energy consumption within the organization" in version 4; EN16 is "total direct and indirect greenhouse gas emissions by weight" in version 3.1, but "direct greenhouse gas (GHG) emissions (scope 1)" in version 4 . The indicators from 2015 to 2017 were once analyzed but the values of indicators in the CSR reports between the former five years and latter three years did not seem to allow for direct comparison. Besides, a new version of GRI Standards was published in 2016 and the indicators were adjusted again. Therefore, it is difficult to track the values of indicators crossing different versions.

Nevertheless, the reports of five years of the eight companies provided plenty of initiatives and indicator values for analysis and comparison. For example, nineteen initiatives were identified for Company $\mathrm{G}$ in Table 3 and seven initiatives for Company A in Table 4; more than 100 initiatives in total were reviewed and identified in the research process. Twenty values were examined for the four indicators for five years for each company; and 160 values in total were examined. Moreover, these initiatives such as renewable energy are current popular practices in reality, although disclosed some years ago; the indicator values are also true data. Therefore, the quantities and quality of the data are acceptable for analysis. The derived results are meaningful and were not discovered before.

The rule used to establish a relationship is "an initiative is implemented in a year and its corresponding indicator's value decreases in the next year." This rule counted the numbers of relationships for many initiatives and indicators. Maybe some other rules 
can be used but this one was adopted because of its simplicity. Studies have shown that great uncertainty is involved in the identification and assessment of environmental impacts [21]. This study's research method adopts the four quantitative indicators and this rule to overcome the uncertainty of the identification and assessment of environmental impacts. There could be other factors influencing an indicator's value year to year, such as the amount of construction activity discussed above. However, they can be studied jointly with the relationship establishment in future research.

This study determined the likelihood of linking initiatives and impact reduction. A company can check the effectiveness of the initiatives by examining the values of environmental indicators [63]. However, the information of initiatives and environmental performance disclosed in CSR reports should not be intentionally justified or concealed [64]. Companies should first implement the effective initiatives required by government regulations. Otherwise, the cost and effort are wasted on implementing the initiatives without evident impact reduction.

Adoption of environmental practices or initiatives could reduce the adverse impacts of construction activities on the environment [38]. However, the extent to which an impact is reduced and the duration of that impact were not considered. These factors need to be investigated. Future research should analyze the extent to which an impact is reduced, the duration of that impact and the cost involved in implementing environmental initiatives. Prioritizing these factors will be useful for decision makers to select the best initiatives for implementation.

This study is exploratory in determining the relationships between environmental initiatives and performance. Although 40 CSR reports of eight companies for five years were examined, the case number can be increased in the future study to verify the likelihood of relationships.

\section{Conclusions}

CSR reports present information on a company's sustainable performance. This study analyzed the environmental initiatives and impacts disclosed in the CSR reports of companies and determined the relationships between them. Eight international construction companies were selected for this study, and their 40 CSR reports were reviewed. Energy, water, emissions, and waste were the four GRI quantitative indicators considered most relevant to construction activities. Their values were used to analyze environmental impacts.

The results show that energy consumption had the largest number of relationships between initiatives and impact reductions; the likelihood for an initiative to reduce energy consumption was approximately $40 \%$. The likelihood for an initiative to reduce water consumption was only $9.4 \%$. Two companies undertook initiatives that had a $50 \%$ likelihood of reducing their environmental impacts, and no relationship was observed for one company. This indicates that initiatives may work for some companies but not work for others. Furthermore, the likelihood for an initiative to reduce environmental impacts was approximately $25 \%$ on average, meaning that roughly one of four companies was able to undertake initiatives to reduce their impact. This result is acceptable because the relationship between initiatives and impact has not been studied in great depth and practitioners have only partial knowledge of it.

Environmental initiatives are implemented by companies and written in CSR reports in practice. Studies identified the relationships between environmental initiatives and environmental performance. However, the influence of initiatives on impact reduction was not investigated. This study reveals that environmental initiatives increased environmental performance with likelihoods. This result supplements and supports the prior studies that only some initiatives are valid, and some companies successfully implement them. A company should check the effectiveness of their environmental initiatives before implementation.

Three factors that would influence the relationship between initiatives and impacts are the amount of construction activity, contents of initiatives, and money spent on initiatives. These need to be examined so as to understand their influence. Future research can analyze the extent to which an impact is reduced and the duration of that impact, as well as the cost 
involved in implementing environmental initiatives. The results will be useful for decision makers to select the best initiatives for implementation.

Author Contributions: Conceptualization, A.S.C. and C.C.; methodology, A.S.C.; software, Y.-L.C.; validation, A.S.C. and Y.-L.C.; formal analysis, A.S.C.; investigation, C.C. and Y.-L.C.; resources, A.S.C. and Y.-L.C.; data curation, C.C.; writing-original draft preparation, Y.-L.C.; writing-review and editing, A.S.C. and Y.-L.C.; visualization, Y.-L.C.; supervision, A.S.C.; project administration, Y.-L.C. All authors have read and agreed to the published version of the manuscript.

Funding: Supported by the Ministry of Science and Technology, Taiwan R.O.C. (grant number: MOST 108-2221-E-006-028).

Conflicts of Interest: The authors declare no conflict of interest.

\section{References}

1. Daub, C.H. Assessing the quality of sustainability reporting: An alternative methodological approach. J. Clean. Prod. 2007, 15, 75-85. [CrossRef]

2. Zou, P.X.W.; Couani, P. Managing risks in green building supply chain. Archit. Eng. Des. Manag. 2012, 8, 143-158. [CrossRef]

3. Zeule, L.O.; Serra, S.M.B.; Teixeira, J.M.C. Model for sustainability implementation and measurement in construction sites. Environ. Qual. Manag. 2019, 29, 67-75. [CrossRef]

4. Gagnon, B.; Leduc, R.; Savard, L. From a conventional to a sustainable engineering design process: Different shades of sustainability. J. Eng. Des. 2012, 23, 49-74. [CrossRef]

5. Krueger, K.; Stoker, A.; Gaustad, G. "Alternative" materials in the green building and construction sector: Examples, barriers, and environmental analysis. Smart Sustain. Built Environ. 2019, 8, 270-291. [CrossRef]

6. Smeets, E.; Weterings, R. Environmental Indicators: Typology and Overview; European Environment Agency: Copenhagen, Denmark, 1999.

7. Jasch, C. Environmental performance evaluation and indicators. J. Clean. Prod. 2000, 8, 79-88. [CrossRef]

8. Gilley, K.M.; Worrell, D.L.; Davidson, W.N.; El-Jelly, A. Corporate environmental initiatives and anticipated firm performance: The differential effects of process-driven versus product-driven greening initiatives. J. Manag. 2000, 26, 1199-1216. [CrossRef]

9. Shi, Q.; Yan, Y.; Zuo, J.; Yu, T. Objective conflicts in green buildings projects: A critical analysis. Build. Environ. 2016, 96, 107-117. [CrossRef]

10. Yusof, N.; Awang, H.; Iranmanesh, M. Determinants and outcomes of environmental practices in Malaysian construction projects. J. Clean. Prod. 2017, 156, 345-354. [CrossRef]

11. Martens, M.L.; Caralho, M.M. Key factors of sustainability in project management context: A survey exploring the project managers' perspective. Int. J. Proj. Manag. 2017, 35, 1084-1102. [CrossRef]

12. Ajayi, S.O.; Oyedele, L.O.; Bilal, M.; Akinade, O.O.; Alaka, H.A.; Owolabi, H.A. Critical management practices influencing on-site waste minimization in construction projects. Waste Manag. 2017, 59, 330-339. [CrossRef]

13. Hussain, K.; He, Z.; Ahmad, N.; Iqbal, M.; Taskheer Mumtaz, S.M. Green, lean, six sigma barriers at a glance: A case from the construction sector of Pakistan. Build. Environ. 2019, 161, 106225. [CrossRef]

14. Onubi, H.O.; Yusof, N.A.; Hassan, A.S. Understanding the mechanism through which adoption of green construction site practices impacts economic performance. J. Clean. Prod. 2020, 254, 120170. [CrossRef]

15. Liao, Z.; Zhang, M. The influence of responsible leadership on environmental innovation and environmental performance: The moderating role of managerial discretion. Corp. Soc. Responsib. Environ. Manag. 2020, 27, 2016-2027. [CrossRef]

16. KPMG. The KPMG Survey of Corporate Responsibility Reporting 2017; KPMG Global Sustainability Services: Amsterdam, The Netherlands, 2017.

17. GRI. Sustainability Reporting Guidelines on Economic, Environmental and Social Performance; Version 3.1; GRI: Boston, MA, USA, 2011.

18. Petrovic-Lazarevic, S.; Perry, M.; Rajan, R. Improving occupational health and safety measures in the Australian construction industry. Zagreb Int. Rev. Econ. Bus. 2007, 10, 17-34.

19. Geng, R.; Mansouri, S.A.; Aktas, E. The relationship between green supply chain management and performance: A meta-analysis of empirical evidences in Asian emerging economies. Int. J. Prod. Econ. 2017, 183, 245-258. [CrossRef]

20. Ardito, L.; Dangelico, R.M. Firm environmental performance under scrutiny: The role of strategic and organizational orientations. Corp. Soc. Responsib. Environ. Manag. 2018, 25, 426-440. [CrossRef]

21. Gangolells, M.; Casals, M.; Gasso, S.; Forcada, N.; Roca, X.; Fuertes, A. Assessing concerns of interested parties when predicting the significance of environmental impacts related to the construction process of residential buildings. Build. Environ. 2011, 46, 1023-1307. [CrossRef]

22. Oke, A.; Aghimien, D.; Aigbavboa, C.; Madonsela, Z. Environmental sustainability: Impact of construction activities. In Proceedings of the 11th International Conference (CITC-11), London, UK, 9-11 September 2019.

23. O'Dwyer, B. Managerial perceptions of corporate social disclosure: An Irish story. Account. Audit. Account. J. 2003, 15, 406-436. [CrossRef] 
24. Roca, L.C.; Searcy, C. An analysis of indicators disclosed in corporate sustainability reports. J. Clean. Prod. 2012, 20, 103-118. [CrossRef]

25. Habek, P.; Wolniak, R. Assessing the quality of corporate social responsibility reports: The case of reporting practices in selected European Union member states. Qual. Quant. 2016, 50, 399-420. [CrossRef]

26. Brammer, S.; Pavelin, S. Factors influencing the quality of corporate environmental disclosure. Bus. Strategy Environ. 2008, 17, 120-136. [CrossRef]

27. Fernandez-Feijoo, B.; Romero, S.; Ruiz, S. Commitment to corporate social responsibility measured through global reporting initiative reporting: Factors affecting the behavior of companies. J. Clean. Prod. 2014, 81, 244-254. [CrossRef]

28. Bewley, K.; Li, Y. Disclosure of environmental information by Canadian manufacturing companies: A voluntary disclosure perspective. Adv. Environ. Account. Manag. 2000, 1, 201-226.

29. Pe, A.A. Relationships between Environmental Indicator Disclosure Levels of International Contractors and Data Sources. Master's Thesis, National Cheng Kung University, Tainan, Taiwan, 2020.

30. Habek, P. CSR reporting practices in Visegrad Group countries and the quality of disclosure. Sustainability 2017, 9, 2322. [CrossRef]

31. Lozano, R. Analyzing the use of tools, initiatives, and approaches to promote sustainability in corporations. Corp. Soc. Responsib. Environ. Manag. 2020, 27, 982-998. [CrossRef]

32. Hartmann, J.; Vachon, S. Linking environmental management to environmental performance: The interactive role of industry context. Bus. Strategy Environ. 2018, 27, 359-374. [CrossRef]

33. Shahab, Y.; Ntim, C.G.; Chengang, Y.; Ullah, F.S. Environmental policy, environmental performance, and financial distress in China: Do top management team characteristics matter? Bus. Strategy Environ. 2018, 27, 1635-1652. [CrossRef]

34. Gomes da Silva, F.J.G.; Gouveia, R.M. Tracking Environmental Performance. Cleaner Production: Toward a Better Future; Springer: Cham, Switzerland, 2000; pp. 401-420.

35. Rodriguez, G.; Alegre, F.J.; Martinez, G. Evaluation of environmental management resources (ISO 14001) at civil engineering construction worksites: A case study of the community of Madrid. J. Environ. Manag. 2011, 92, 1858-1866. [CrossRef]

36. Kourmpanis, B.; Papadopoulos, A.; Moustakas, K.; Stylianou, M.; Haralambous, K.J.; Loizidous, M. Preliminary study for the management of construction and demolition waste. Waste Manag. Res. 2008, 26, 267-275. [CrossRef]

37. Veleva, V.; Hart, M.; Greiner, T.; Crumbley, C. Indicators for measuring environmental sustainability: A case study of the pharmaceutical industry. Benchmarking Int. J. 2003, 10, 107-119. [CrossRef]

38. Birkeland, J.L. Positive development and assessment. Smart Sustain. Built Environ. 2014, 3, 4-22. [CrossRef]

39. Wang, J.; Li, Z.; Tam, V.W. Identifying best design strategies for construction waste minimization. J. Clean. Prod. 2015, 92, 237-247. [CrossRef]

40. Batista, A.A.S.; Francisco, A.C. Organizational sustainability practices: A study of the firms listed by the corporate sustainability index. Sustainability 2018, 10, 226. [CrossRef]

41. Son, H.; Kim, C.; Chong, W.K.; Chou, J.S. Implementing sustainable development in the construction industry: Constructors' perspectives in the US and Korea. Sustain. Dev. 2011, 19, 337-347. [CrossRef]

42. Alazzani, A.; Wan-Hussin, W.N. Global Reporting Initiative's environmental reporting: A study of oil and gas companies. Ecol. Indic. 2013, 32, 19-24. [CrossRef]

43. Clarkson, P.M.; Li, Y.; Richardson, G.D.; Vasvari, F.P. Revisiting the relation between environmental performance and environmental disclosure: An empirical analysis. Account. Organ. Soc. 2008, 33, 303-327. [CrossRef]

44. Bednarova, M.; Klimko, R.; Rievajova, E. From environmental reporting to environmental performance. Sustainability 2019, 11, 2549. [CrossRef]

45. Latridis, G.E. Environmental disclosure quality: Evidence on environmental performance, corporate governance and value relevance. Emerg. Mark. Rev. 2013, 14, 55-75. [CrossRef]

46. Walls, J.L.; Berrone, P.; Phan, P.H. Corporate governance and environmental performance: Is there really a link? Strateg. Manag. J. 2012, 33, 885-913. [CrossRef]

47. Chen, L.; Tang, O.; Feldmann, A. Applying GRI report for the investigation of environmental management practices and company performance in Sweden, China and India. J. Clean. Prod. 2015, 98, 36-46. [CrossRef]

48. Chen, P.H.; Ong, C.F.; Hsu, S.C. Understanding the relationships between environmental management practices and financial performances of multinational construction firms. J. Clean. Prod. 2016, 139, 750-760. [CrossRef]

49. Li, S.; Ngniatedema, T.; Chen, F. Understanding the impact of green initiatives and green performance on financial performance in the US. Bus. Strategy Environ. 2017, 26, 776-790. [CrossRef]

50. Hang, M.; Klingeberg, J.G.; Rathgeber, A.W. It is merely a matter of time: A meta-analysis of the causality between environmental performance and financial performance. Bus. Strategy Environ. 2018, 28, 257-273. [CrossRef]

51. Nuber, C.; Velte, P.; Horisch, J. The curvilinear and time-lagging impact of sustainability performance on financial performance: Evidence from Germany. Corp. Soc. Responsib. Environ. Manag. 2020, 27, 232-243. [CrossRef]

52. Krippendorff, K. Content Analysis: An Introduction to Its Methodology; Sage Publications: Thousand Oaks, CA, USA, 2004.

53. Willetts, R.; Burdon, J.; Glass, J.; Frost, M. Corporate responsibility practices in engineering consultancies. Int. J. Constr. Manag. 2011, 11, 19-35. [CrossRef]

54. Jiang, W.; Wong, J.K.W. Key activity areas of corporate social responsibility (CSR) in the construction industry: A study of China. J. Clean. Prod. 2016, 113, 850-860. [CrossRef] 
55. GRI. A Snapshot of Sustainability Reporting in the Construction and Real Estate Sector; Global Reporting Initiative: Amsterdam, The Netherlands, 2008.

56. GRI. Sustainability Disclosure Database. Available online: https://database.globalreporting.org/ (accessed on 30 October 2020).

57. Eisenhardt, K.M. Building theories from case study research. Acad. Manag. Rev. 1989, 14, 532-550. [CrossRef]

58. Xia, B.; Olanipekun, A.; Chen, Q.; Xie, L.; Liu, Y. Conceptualising the state of the art of corporate social responsibility (CSR) in the construction industry and its nexus to sustainable development. J. Clean. Prod. 2018, 195, 340-353. [CrossRef]

59. Dobrovolskienè, N.; Tamošiūnienè, R. An index to measure sustainability of a business project in the construction industry: Lithuanian case. Sustainability 2016, 8, 14. [CrossRef]

60. Lin, S.H. Difficulty Assessment and Reason Analysis for Achieving Construction Activities in Greenroads. Master's Thesis, National Cheng Kung University, Tainan, Taiwan, 2013. (In Chinese).

61. Brambila-Macias, S.A.; Sakao, T. Effective ecodesign implementation with the support of a lifecycle engineer. J. Clean. Prod. 2021, 279, 123520. [CrossRef]

62. Barahona Diaz, J.E. EMS Implementation Barriers and Possible Improvement Methods. Master's Thesis, National Cheng Kung University, Tainan, Taiwan, 2017.

63. Bal, M.; Bryde, D.; Fearon, D.; Ochieng, E. Stakeholder engagement: Achieving sustainability in the construction sector. Sustainability 2013, 5, 695-710. [CrossRef]

64. Talbot, D.; Boiral, O. GHG reporting and impression management: An assessment of sustainability reports from the energy sector. J. Bus. Ethics 2018, 147, 367-383. [CrossRef] 